\title{
College Students' Internet entrepreneurship Status Investigation and Trend Analysis: Some examples of Jinan university
}

\author{
Wang Dongling \\ Department of economics and management, Shandong Yingcai University, Jinnan, \\ 251400, China \\ email: 40668058@qq.com
}

Key words: College Students; Internet entrepreneurship ; Status Investigation; Trend Analysis

\begin{abstract}
The total amount of college graduates continues to grow. The mismatch between supply and demand and structural contradiction and employment channels are make the employment situation of college students very difficult. In order to solve the college students' employment problem, encouraging entrepreneurship to create more employment opportunities is an effective way to alleviate employment pressure. College students' Internet entrepreneurship not only can effectively alleviate the employment pressure, increasing the employment channels, but also improve the comprehensive quality of college students and help to build a harmonious credit society. Through 5 investigation and analysis of the present situation of Jinan university students' network entrepreneurs, this article finds out the problems of the college students in starting Internet entrepreneurship, and analyzes the development trends of internet entrepreneurship. Today's college student employment difficulty has become a common phenomenon. College students' network entrepreneurship not only solves the problem of employment and drive regional economic growth, which has great significance.
\end{abstract}

\section{Introduction}

\section{Research Background}

The rapid development of China economy and the upgrading and adjustment of industrial structure,which stimulates the vigorous development of education in china. Chinese public university and private university continued to expand enrollment scale, although the popularization of higher education, in a certain extent is very common, but a large number of graduates in the every followed year make the employment situation of university students goes from bad to worse.

First, the total number of college graduates continue grow. The State Department of human resources and social security statistics data show that in 2009 the number of college graduates nationwide reached six million and 100 thousands, and this data is expected to grow in follow 3 years as the annual growth rate of 500 thousand.

Second, college graduates employment opportunities is significantly reduced. In 2010, the new added jobs in the county over 900 millions, which reduces 100 millions in the contrast of last year,and in addition of other 300 million people for the natural attrition, the total available jobs in this year is 12 millions and these positions also to ensure that 5 million laid-off workers are employed even demobilized soldiers community employment.

Third, supply and demand does not match the structural contradictions, colleges and universities of professional settings and market demand mismatches.

Fourth, college graduates employment channels unimpeded. The main channel for employment of college graduates is a non-public enterprises and small and medium enterprises. But a graduate from the non-public enterprises and go to the public ownership of enterprises and institutions exist a lot of difficulties, because of the restriction of social insurance, archives management, cadre status. Some non-public enterprises management is not perfect, the system is not perfect, it is difficult to retain college graduates, and graduates themselves, influenced by the traditional concept of employment, are unwilling to go to the non-public enterprises Although there is a great demand for colleges students in urban and rural basic level, but because of policy, system is not perfect, so 
many college students are unwilling to go to work in the grassroots.

\section{Entrepreneurial Status of College Students' Network}

\section{Structural Characteristics of College Students' Network of Entrepreneurs}

\section{(a). Gender Structure}

As of December 2014, 5 universities in Ji'nan as the survey showed the survey sample of 1000 students in the male and female ratio of 51:49, the network can be seen in terms of gender differences in entrepreneurship is not.

\section{(b).The Structure of Colleges}

Survey data show that Internet entrepreneurs 58\% for college students, 33\% for undergraduates, graduate students and other accounts for only a small percentage of the. In recent years, due to the increasing employment pressure of college students, college students in the employment market face brutal competition in the undergraduate and graduate students, many people cannot find an ideal job. As shown in figure 1-2:

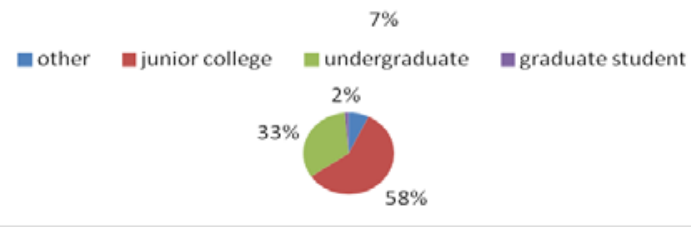

Fig 1 Comparison of gender structure chart of 1-2 Internet entrepreneurs

\section{(c). Professional Structure}

According to the survey data show that economics students share entrepreneurial students the proportion of $63.28 \%$. Significantly higher than other professional students proportion of entrepreneurs. The proportion of science students is $10.21 \%$, with the students professional quality also have close ties. Science and technology, especially the IT professional will contact network more than students in other disciplines, the development of more understanding of the Internet and the change of .

\section{College student entrepreneurial team}

(a) .the number of initial venture

The initial number of 52.34\% college students' Internet entrepreneurship for 1 people. The data also indirectly reflect from taobao.com, pat Network, such as Internet entrepreneurship platform of dangdang.com team are low, so most of the students choose the Internet entrepreneurship. By 2 people, 3 people, 4 people team accounted for $16.21 \%, 9.32 \%, 6.28 \%$.

(b). business partners

Most of students' Internet entrepreneurship partners are classmates or friends accounted for $44.53 \%, 31.22 \%$, in addition to a considerable proportion of the students chose to become a partner or spouse and relatives. As shown in figure 2:

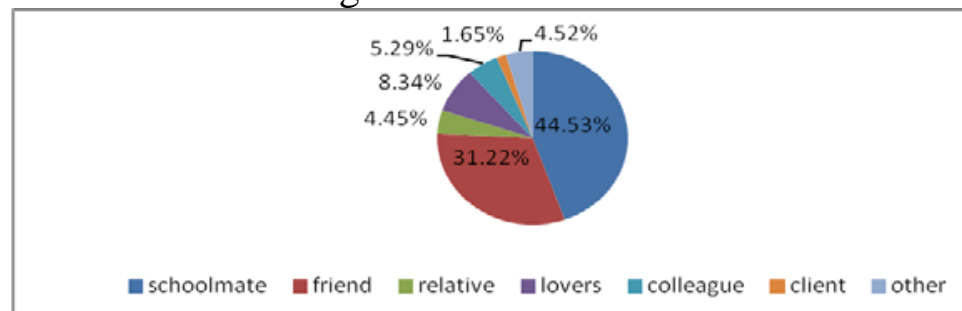

(c).The number of entrepreneurial employee

Figure 2 college Internet entrepreneurship partner situation

According to the survey data, the vast majority of the network of college students did not hire employees, employee ratio as high as $86.78 \%$, which confirms the entry conditions of Internet entrepreneurship less investment. Hire 1 to 2 people accounted for only $9.87 \%$,

Since most of the network of entrepreneurial students had no employees, so employees of 
sources is impossible, even if it is an employee owned business, employees usually chose the school work demand alumni or students, accounting for $78 \%$ of employees, the other is derived from other schools are university graduates and staff. As shown in figure 3:

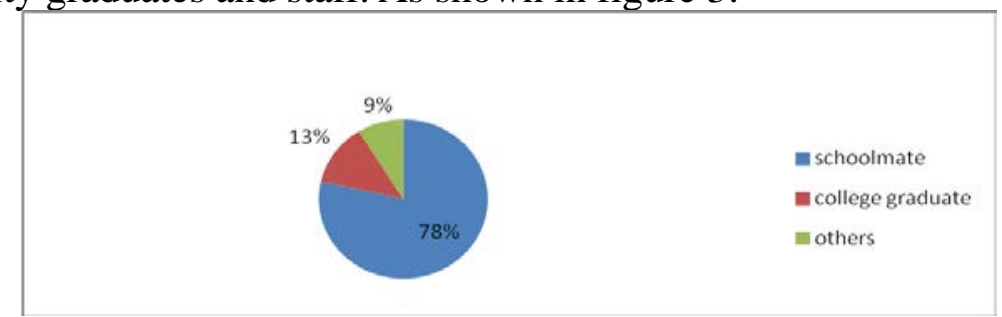

Figure 3 college Internet entrepreneurship employment sources

\section{College Internet entrepreneurship Platform}

Survey data show that most of the Internet entrepreneurship students will choose the existing platform, such as Taobao, pat Network, eBay and other relatively mature network platform, according to the monitoring data of the China Electronic Commerce Research Center 100EC.CN, Taobao market position is still strong, until December 2013 Taobao accounted for 97\% of all. Eachnet.com, accounted for 3\%, accounting for $0.1 \%$.

Taobao.com share in the network shopping market has accounted for $96.5 \%$, while eachnet.com and pat net market share was $0.1 \%$ and $3.4 \%$ [8]. 2014, the rise of derivative, a year short sellers derivative more than 1000 million, think Taobao in the 10 years before it reaches the digital, making the most of the network does poineering work of college students choose Taobao, micro letter as a platform, the proportion of 79.35\%, clap nets and eBay's choice of students accounted for only $11.82 \%$. There are some students choose to build a platform, with the autonomy and flexibility of higher transaction, as shown in figure 4

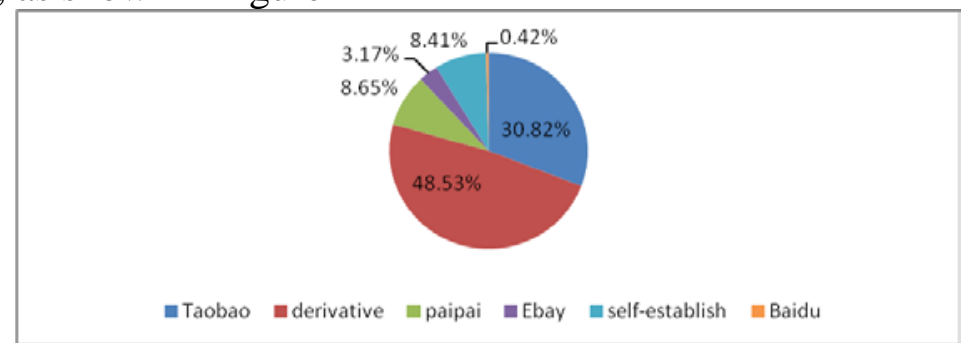

Figure 4 college Internet entrepreneurship e-commerce platform structure

\section{Business Students' Internet entrepreneurship}

\section{(a).The main Type of Products}

Main business of college students in the type of products, apparel, beauty and skin care products accounted for $41.23 \%, 16.44 \%$, other products or services and digital products products respectively accounted for 13.4 and $15.35 \%$, this proportion also fits the China Internet Network Information Center released in June 2013, 20138 years China online shopping Research Report, the report shows on the Internet to buy clothing home accessories of consumers accounted for the total number of Internet users in the shopping 58.23\%, and through the network to buy books, audio-visual products and cosmetics and jewelry are ranked second and third place, as shown in Figure 5

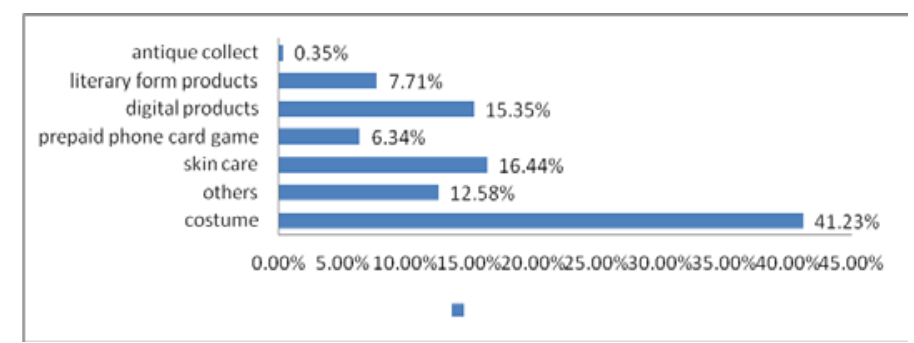

Figure 5 college Internet entrepreneurship mainly engaged in commodity types 


\section{(b). The Source of the Product Sales}

Sources of sales of products inspection of Jinan university students, through wholesalers purchase accounted for 51.23\%, produce their own just extremely individual phenomenon, most of the students through wholesalers, retailers and manufacturers to take delivery of the goods, are generally not directly production, as shown in Figure 6:

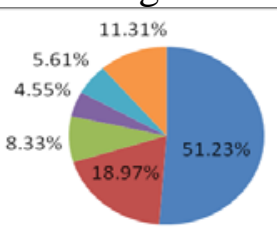

Figure 6 college Internet entrepreneurship sales products

\section{College Sudents' Network Startup Funds}

\section{(a). Start-up Capital}

Because the Internet entrepreneurship in the micro business, such as taobao.com, eachnet.com, start-up funding requirements is not high, limited college funds, investment is not so. According to the survey data, undergraduate network does poineering work investment of less than 1000 yuan as start-up capital occupies $71.5 \%$, the investment of 1000 to 2000 yuan $14.00 \%, 2000$ to 3000 yuan accounted for $5.50 \%$, the investment 3000 to 5000 yuan accounted for $4.5 \%$, the investment of more than 5000 yuan accounted for only 3.50\%.

\section{(b).The Source of Start-up Capital}

Network of entrepreneurial students start funding sources, full personal investment accounted for $57.02 \%$, the partner to raise funds in the possession of $30.30 \%$, to $4.70 \%$ for others to borrow, other combinations of possession of $4.51 \%$, funded by the University, bank loans or government funded $3.47 \%$. As shown in figure 7 :

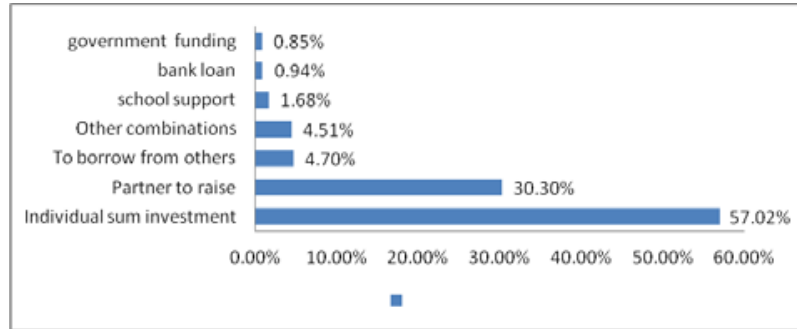

Figure 7 Internet venture funding

\section{College Students Internet entrepreneurship Income}

\section{(a). average monthly sales}

Due to the college students mostly belongs to the early entrepreneurs, so the income is not high, the survey showed; network of entrepreneurial students monthly sales of less than 1000 yuan in possession $72.30 \%$, sales in 1000 to 2000 yuan accounted for $9.71 \%$, 2000 to 5000 yuan share 8.20\%, with $9.79 \%$ students monthly sales in more than 5000 yuan.

\section{(b). The First Transaction Time Point}

According to the survey, undergraduate network does poineering work in the shop opened within 1 week happening brushstroke business occupied 32.25\%, opened two weeks occurred first transaction $38.53 \%$ share, share $18.25 \%$ a month. That is to say within 1 month occurred in the first transaction possession $92.03 \%$, the need for more than 1 month before trading possession of $7.97 \%$.

\section{(c).The Level of Income Satisfaction}

For the level of income satisfaction of College Students' Internet entrepreneurs, 32\% of business students who are not satisfied, $48 \%$ of the college students' basic satisfaction, $7 \%$ of college students are very satisfied with, say not clear possession of $13 \%$, visible for more than half of the students for current income not satisfied, which is bound to influence students' Internet 
entrepreneurship of passion.

\section{There are Students' Internet entrepreneurship Problems}

College Students' Entrepreneurship in China showing the situation to start a large number of students, Domestic college students mainly face the following problems: first, high-tech venture, it is difficult to open the market, but also easy to be imitated; second, entrepreneurship education in Colleges and universities lag, theory and practice of light weight, can't give enough guidance to students' Internet entrepreneurship; third, college students generally financing difficulties, can melt into the the fund is relatively .

\section{Countermeasures to Promote Students' Internet entrepreneurship}

First, I think it should first improve our social culture, change their concept of employment, now is not the previous workers era, today's graduate students, not a graduate can into the departments and units, government units, parents should also change the original concept, encourage children to start their own businesses, the state also encourages people to venture to promote employment. In addition, college students should take part in some activities, only to learn book knowledge is not enough, practice tests truth, only through practice, can we truly achieve mastery through a comprehensive study of the subject, the United Nations education, scientific and Cultural Organization (2009) that: Entrepreneurship Education and academic education, vocational education education has the same important position, entrepreneurship education become learning "the third passport" [9]. Second, government and schools also have corresponding measures to promote college students' entrepreneurial network, Third, actively promote the construction of network security, so the students will have a good Internet entrepreneurship platform can enhance network security by means of technology; and credit evaluation to judge, is the poor response to the degree of credibility, so that you can make the credit degree of good businesses continue to remain in the market, the elimination of those bad businesses, thereby maintaining network security.

\section{Conclusion}

The present situation of college students based on the network, find the problems and give the corresponding countermeasures. Government, enterprises and universities also for college students provides a good network environment for entrepreneurship, and give a series of policy concessions, students start to want to succeed, depends on not only passion is more important is to analyze all kinds of risks in the entrepreneurial network, can effectively avoid that through entrepreneurship gradually accumulate experience and improve their overall quality, work together to improve network poineering success rate.

Funds support: National Education Science Program（DFA1418）

\section{References}

[1] 24 times China Internet network development state statistic report [R]. China Internet network information center, 2009.

[2]Hu gui-lan . Based on taobao C2C platform research [J]. Journal of college students online entrepreneurship education theory in colleges and universities, 2009, 3 (4):83-87.

[3] Chen de-ren, Wu ji-yi. College students' network pioneering [M]. Beijing: higher education press, 2011, (1) 10-12.

[4]Liu Xiao-yan. Entrepreneurship: a new way of university students' employment [J]. China talent, 2008, (9):6-9.

[5] WeiJin. Between adaptation and transcendence: college students' entrepreneurship education [J]. China's higher education research, 2004, (4): 73-74.

[6] Guillena M F,Suarez S L.Developing the Internet: entyepreneurship and public policy in 
Ireland,Singapore,Argentina,and Spain[J].Telecommunications Policy,2001,(25):349-371.

[7] Ajzen,I.The theory of planned behavior.Organizational behavior and Human Decision Processes.1995(50).

[8]Yang Bao-zhong. American college student entrepreneurship practice activities and its enlightenment [J]. Journal of foreign education research, 2005, 32 (11): 49-51.

[9] Waesche N M,Cheltenham.Internet Entrepreneurship in Europe: Venture Failure and the Timing of Telecommunications Reform [M]. Edward Elgar Publishing.2003. 